Encrucijada/Crossroads: An Online Academic Journal

Issue 1, Volume 12003

\title{
Latino Learners of Spanish: The Who, the Why and the What-for
}

\author{
Gustavo Mejía \\ Associate Professor of Spanish/Modern Languages \\ Central Connecticut State University
}

When we think about the teaching of Spanish in the United States, we normally have in mind English-speaking students who want to learn Spanish as a second language. Indeed, in the majority of language departments, there is nothing else. However, a relatively new and growing phenomenon is taking place at the university level with the arrival of increasing numbers of Latino students who are looking for ways to improve their competence in the language they learned at home, though they never studied it. The purpose of this essay is to reflect on this phenomenon and I hope to touch on some points that will provoke some discussion. It seems necessary, however, to start speaking about teaching Spanish to native speakers at college level by looking back to see how this field has become what it is.

One of the first initiatives to teach Spanish to Spanish speakers in a rather general way in the United States took place in Florida's Dade County in the early 1960s. The program was directed to Cuban children, and by 1970 it had been implemented in over 100 elementary, junior- and senior high schools, involving some 120 native Spanish speaking teachers and serving more than 15,000 students (AATSP 620-21). This program became the model for a proposal by the American Association of Teachers of Spanish and Portuguese, which, in 1970 commissioned a report that was published in Hispania in 1972. The report clearly stated that the Association would not continue to "accept the embarrassing anomaly of a language policy for American education which on the one hand seeks to encourage and develop competence in Spanish among those for whom it is a second language, and on the other hand, by open discouragement, neglect, and condescension, destroys it for those who speak it as a mother tongue" (620). It therefore called for the establishment of programs at all levels of schooling specially designed to "give the learner full command of and literacy in world standard Spanish"!(620). As can easily be imagined, this report unleashed the forces of nature and society alike and created quite a stir in the teaching profession. Looking back, however, the importance of the report lies in the fact that it delimited the arena on which the debate was to take place in the following years, and many of the points of discussion that continue to emerge today were 
effectively formulated — though not necessarily effectively addressed - in that report.

Alongside academic developments, one must mention the struggles of the civil rights movement, which obtained some landmark rulings, among which the following are often mentioned:

- Serna v. Portales Municipal Schools. This ruling upheld the plaintiffs' claim that they had been unlawfully discriminated against as a result of the defendant's "educational program tailored to educate a middle-class child from an English-speaking family without regard for the educational needs of a child from an environment where Spanish is the predominant language" (Piatt!3);

- Lau v. Nichols. Although this case involved, not the Spanish language, but Chinese, this ruling established that the plaintiffs had been deprived of rights under the Civil Rights Act of 1964 and ordered the "school systems to take remedial steps to rectify language deficiency problems" (Piatt 4, also Lopez 3) and

- Hernandez v. Erlenbusch, a case where a Spanish speaker was granted the right to speak Spanish while having a beer at a bar, as it linked language discrimination to racial discrimination.

So by the mid 1970s, we find that the right to use one's own language had made its way into American jurisdiction. Although not always (see García v. Gloor, Jara v. Municipal Court, Guerrero v. Carleson) (Piatt 8-9), the courts were often ruling in favor of the individual's right to use his or her own language in different situations. Often they granted a person's right to bilingual instruction and ordered the school systems to provide bilingual educational programs. This situation began to rebut the so-far predominant policy embodied in President Roosevelt's widely quoted dictum: "We have room for but one language here and that is the English language, for we intend to see that the crucible turns our people out as Americans, of American nationality, and not as dwellers in a polyglot boarding house" (cit. Piatt 11).

At that time, however, most of the action was taking place in elementary and secondary education, and although some universities, particularly those in areas with a high concentration of Latino population, were beginning to offer Spanish courses for native speakers, the issue had not become heated at the college level. It was necessary to wait until the early 80 s for the issue to reach the universities, where the debate centered on a few pointed questions: who were those students wanting to study Spanish? Why were they studying it? And what should be the purpose of a university program addressed to them?

Encrucijada/Crossroads 1.1 (2003): 25-32 
As for the first question, the answer was generally given in terms of global statistics taken from the US Bureau of the Census, which indicated the number of non-English speakers living in the United States, the areas where they concentrated, and the major ancestral nationalities represented overall (Lopez 13 ). In some cases, a few comments were added to specify what each individual professor encountered in his or her classroom, but no one was able to produce a statistical analysis at the local level, not to mention state- or national levels. Unfortunately, some twenty years later, one finds that the situation continues to be very much the same. There is an appalling lack of data collected from actual students who are studying the language, so we know very little about them, and the little that we know about them is not supported by statistics, but rather by the aggregate impression given by the few and isolated case studies reported in the literature. Often they are referred to as having poor study skills such as "listening, following directions, time management, task accountability and rigorous selfdiscipline" (Feliciano 9, also Girard Lozano 95). Their level of command of the Spanish language is described as encompassing a wide range, from welldeveloped oral skills to comprehension only, and there tends to be a consensus around their limited literacy in the language. These students are described as being under "constant pressure from English," having "limited contact with educated speakers of their native language, and feelings of inferiority about their own speech and culture" (Parla 2).

As far as my own observations I the classroom, it seems that the description presented above continues to hold true today in all but one point. The problem of differing levels of proficiency in Spanish continues to exist and tax the effectiveness of this type of program. The limitation in general study skills has not been changed significantly, even though many of the current students of Spanish at college level went through bilingual education at some time in their schooling. What seems to have changed in the last few years is the confidence they have developed about their language and the pride in their culture. With Latinos about to become the largest minority in the country; with the visibility that some Latino role models have acquired lately, and the wide-ranging presence of the Spanish language in everyday life in America, these students no longer feel under pressure from English and, on the contrary, feel quite optimistic about their future, both as individuals and as a group. They are proud of their heritage, aware of the improvement, and conscious of the many possibilities that are now open to Latinos:

Yo siento que el futuro de los hispanos va a tener un efecto positivo [sobre] todos los americanos [...] Si nosotros como hispanos hacemos nuestra parte para promover los estudios en la universidad y también involucrarnos a nosotros mismos en la 
comunidad donde vivimos, yo creo que el resultado puede ser positivo.

El futuro de los hispanos en los EEUU se ve muy positivo. Los hispanos hoy día se están preparando y estudiando más que nunca. Los jóvenes están más motivados y más dedicados.

nuestra gente latina tiene más oportunidades que en [cualquier] otro tiempo. Yo, por ejemplo, nunca pensaba que podía [llegar a] ser un maestro, pero ahora estoy feliz que voy a hacer muchos cambios en la educación para la gente latina y la gente de mi comunidad.

En [poco] más de medio siglo los latinoamericanos han tenido un gran impacto en la cultura y el pueblo americano. Uno lo que tiene que hacer es [nada] más activar el televisor y puede ver el ambiente vivo y caliente del sabor hispano. Es como si estuviéramos invadiendo el país: el lenguaje, la comida, la música, las películas, la ropa [...]. Absolutamente todos los elementos de la cultura latinoamericana están siendo asimilados. (Quoted with permission from students' papers. Names withheld by agreement).

As for the second question - why were these students coming to study Spanish - the answers tended to be two-fold: they wanted to learn Spanish in order to develop, recover or reactivate their native tongue, on the one hand, and because they were aware of the advantages that bilingualism could bring them in the job market (Aparicio 233). These different motivations for studying the language could, of course, coexist in the same individual in varying degrees. These answers, however, were not described on the basis of an empirical study of individuals studying the language, but rather they were derived from theoretical studies, such as, for example, W.E. Lambert's, who defined two types of motivation for studying a language: instrumental, if it reflected utilitarian values, such as improving one's position at work, or integrative, if it reflected an orientation "to become a potential member of the other group" (102). Lacking empirical data, the question about the students' reasons for studying Spanish continues to be posed and answered along the same lines. A significant difference, however, is that those Latinos who are now studying at university level today tend to perceive their opportunities in a more favorable way than they did a decade ago. Their optimism about their future seems to be based on the perceived opening of new opportunities in the job market and, therefore, the instrumental motivation seems more grounded in a perceived social reality.

Encrucijada/Crossroads 1.1 (2003): 25-32 
Obviously, this perception is linked to the visibility that Latino culture has taken in the last decade, a visibility epitomized in last year's [1999] Newsweek magazine's front-page coverage of the Latino community in the United States. Several commentators, however, have questioned the nature of this supposed coming of age of the Latino community, and one of them, Beatriz Pastor, points out that the social reality of most Hispanics who live in this country continues to be defined by poverty, illegality, discrimination, and inferior education, housing and medical assistance, among other traits. She suggests that the image which we are being sold "reafirma el modelo homogeneizador impuesto por el estado americano al reducir la multiplicidad cultural, lingüística y económica de esa comunidad a un sólo término: Hispanics." Indeed, what is at stake here is both the desirability and the possibility of an integration of Latinos into mainstream America.

Perhaps the most difficult of the three questions - the one about the purpose of a program to teach Spanish to native speakers - it is also the one that has the deepest implications both for curriculum development, and in political terms. One should perhaps recall that before the 1970s, the prevailing reaction of teachers who encountered an occasional native speaker in their Spanish as a second language classes was to try to eradicate the native speaker's dialectal Spanish and turn him or her into a speaker of world standard Spanish, the variety of Spanish that was normally taught to non-native speakers. This attitude, which met not only with failure, but also with frustration and humiliation by the native speakers, has been widely documented (Valdes). Since the debate over this point started, however, the answers have ranged between two extreme positions. As we have seen, the AATSP report was clear in stating that such programs should ultimately "give the learner full command of and literacy in world standard Spanish," although it suggested that this process should be done with care not to demean the students' own kind of Spanish (621). A middle-of-the-road position that seems to have gained popularity is that of claiming biloquialism or bidialectalism as the objective (Valdés). At the other extreme, however, is the complete rejection of standard Spanish:

our primary rationale for learning and maintaining Spanish is not so that it will serve as a link to Latin America, but so that it will become a strengthening and reinforcing bond for chicanismo within our own communities. Standard Spanish will not only detract us from this goal, it will be an alienating factor. We cannot go into our communities to talk to the people in standard Spanish and expect to effectively gain a feeling of confianza and carnalismo. To do this naturally and effectively, we must use the language of the people, our language [...]' (cited in Lovas). 
One other point has gained more and more presence in today's perspective on Latino learners of Spanish. The language should lead to the study of the culture. It is not enough to be bilingual; the real goal is to become bicultural. But, in spite of its clarity, this observation is not free of controversy. Indeed, a number of questions and problems arise when one starts to think about what Latino culture to teach, how does Latino culture relate to Latin American and Spanish cultures, and above all, when one questions whether the teaching of culture should aim at the perpetuation of some of its most pervasive and conservative traits or whether it should aim at the critical examination of Latino culture in order to change it in positive ways.

In concluding these brief remarks, what becomes clear is that this is a matter that will not be resolved in academic or scholastic terms, but rather in purely political terms. What must be decided is what is or what should be the social and political role of Latinos in the United States and what is or should be the role of Spanish in their lives. Some may think that the purpose of such a program is to help some of the more educated members of the community improve their qualifications. This would in turn allow them to get better jobs in international trade and banking so that they can successfully represent the interest of American businesses and politics in the Spanish speaking world outside the United States, and thus become part of mainstream America. From this perspective, then, the goal of Spanish for native speakers programs should be to help them become confident and educated speakers and writers of both their native variety of Spanish and world standard Spanish. At the same time, these programs could have the objective of helping them develop the study- and work skills they have not learned in school. And as an ultimate goal, these programs would help Latino students become confident and educated speakers and writers of English as well, and thus be prepared to occupy the positions in international trade and businesses that are now being taken by Latin Americans and by secondlanguage speakers. As Guadalupe Valdés puts it, "what we must do instead is concentrate on what the Spanish-speaking student needs, on what he doesn't know in his own 'dialect' or in standard Spanish. Very simply, we must teach him to read and write!" (Spanish 1042). For others, however, the objective is to create agents of change within the community who can go back to their people to build a grass roots movement, and to reinforce communal bonds. For them, clearly, the objective should be to develop their ability to speak their dialect. It must be noted, however, that if one takes this position, one may find Spanish to be altogether out of the landscape. In the words of Hernandez-Chavez, "The important goal is the development of a community-educationally, economically, socially, politically - through Spanish, through English, or bilingually" (33). Language, then, becomes a negotiable commodity.

Encrucijada/Crossroads 1.1 (2003): 25-32 


\section{Works Cited}

American Association of Teachers of Spanish and Portuguese. "Teaching Spanish in School and College to Native Speakers of Spanish." Hispania 55 (1972): 619-31.

Aparicio, Frances R. "Teaching Spanish to the native Speaker at College Level." Hispania 66 (1983): 232-39.

Feliciano, Wilma. "The Spanish for Native Speakers Program at State University New York at Albany". ERIC (1980): ED205028.

Girard Lozano, Anthony. "Teaching Standard versus Non-Standard Spanish in a Study Abroad Program." Social and Educational Issues in Bilingualism and Biculturalism. Eds. Robert St Clair, Guadalupe Valdés, and Jacob Ornstein-Galicia. Washington: University Press of America, 1981. 93100.

Hernández-Chávez, Eduardo. "Native Language Loss and Its Implications for Revitalization of Spanish and Chicano Communities" Latinos in the United States. Ed. Antoinette Sedillo López. New York: Garland Publishing, Inc., 1995. 24-40.

Lambert, Wallace E. “A Social Psychology of Bilingualism.” Journal of Social Issues 23 (1967): 91-109.

Lopez, Meliton. "Bilingual Education for Latinos." Bilingual Education and the Latino Student. Ed. Leonard A. Valverde. Washington: Association for Supervision and Curriculum Development, 1978. 1-15.

Lovas, John C. "Language Planning in a Multilingual Community in the U.S." New Directions in Second Language Learning, Teaching and Bilingual Education . Eds. Marina K. Burt and Heidi C. Dulay. Washington: TESOL, 1975. 113-22.

Parla, JoAnn. "Theoretical and Practical Aspects of Teaching Spanish to Bilingual Students." ERIC (1983): ED240841.

Pastor, Beatriz. "Hispánicos en USA: ¿Hacia una nueva definición de comunidad?" On line document, 17 Nov. 1999. http://www.elpais.es/p/d/debates/bro4.htm, 1 Feb 2000.

Piatt, Bill. "Toward Domestic Recognition of a Human Right to Language." Latinos in the United States . Ed. Antoinette Sedillo López. NewYork: Garland Publishing, Inc., 1995. 1-22.

Valdés, Guadalupe. "Spanish as a native language.” Hispania 56 (1973): 1042.

---. "Language Development versus the Teaching of the Standard Language" Social and Educational Issues in Bilingualism and Biculturalism. Eds. 
Robert St Clair, Guadalupe Valdés, Jacob Ornstein-Galicia. Washington: University Press of America, 1981. 46-62.

Encrucijada/Crossroads 1.1 (2003): 25-32 